\title{
Mevrouw Van Dalen wacht op antwoord
}

JOB VAN AMERONGEN

'W arom ben ik hier eigenlijk? Het aantal keren per dienst van acht uur dat mevrouw Van Dalen deze vraag stelt, heb ik nooit geturfd. Maar een frequentie van vijftig zal ze zeker halen. Het antwoord bevredigt eigenlijk nooit. 'Omdat u zorg nodig hebt,' hoorde ik een collega laatst zeggen. In het geval van mevrouw Van Dalen is dat een waarheid als een koe, maar een waarheid die ze desondanks ernstig wenst te betwisten. 'En waar heb ik dan wel zorg bij nodig?' Mevrouw Van Dalen stelt de vraag eerder verbaasd en vol onbegrip dan boos en wanhopig. 'Nou, we komen hier toch iedere morgen om $u$ te helpen met wassen en aankleden?' De boodschap van collega Ellen wordt met zusterlijke blijheid en enthousiasme uitgesproken.

'Ik zie u toch anders echt voor het eerst,' repliceert mevrouw Van Dalen. 'En wassen en aankleden kan ik nog prima zelf!' Zij behoort duidelijk niet tot de categorie mensen die je zomaar een zorgbehoefte aanpraat.

'En straks smeer ik weer een lekkere boterham voor u,' probeert Ellen het opnieuw. Aan alles hoor je dat het een boterham gaat worden die alle eerder door Ellen gefabriceerde boterhammen - en dat zijn er heel wat! - gaat overtreffen. 'Straks smeert u weer een lekkere boterham voor me...' Mevrouw Van Dalen spreekt de woorden berustend uit. Haar waardering voor de gesmeerde boterham is merkbaar anders dan die van haar zorgverlener. Die maakt ondertussen routineus een bed op.

Even later tref ik mevrouw Van Dalen in de huiskamer achter een zichtbaar met

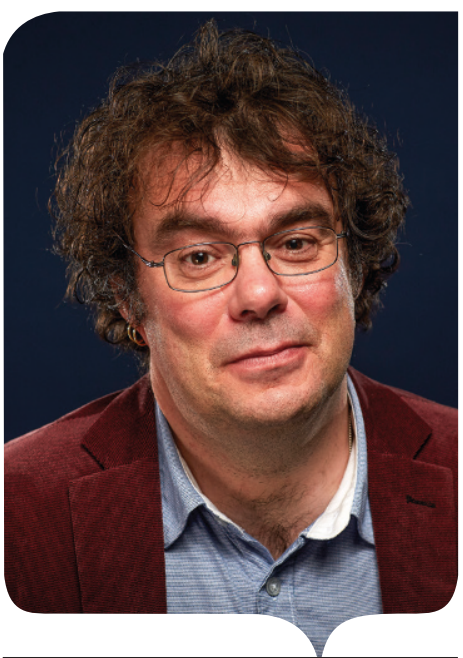

太 Job van Amerongen werkt als verpleegkundige op de dagbesteding voor jonge mensen met dementie 'De Luwte' van de Zonnehuisgroep in Amstelveen en als projectverpleegkundige dagbesteding voor'Nieuw Vredeveld'van de Stichting Brentano, ook in Amstelveen.

liefde gesmeerde boterham met hagelslag. Ik leg even mijn hand op haar schouder en wens haar smakelijk eten. Mevrouw Van Dalen kijkt op en stelt me een niet geheel onverwachte vraag: 'Waarom ben ik hier eigenlijk?' Het is een kwestie die haar nu al maandenlang bezighoudt. Omdat ik weet dat een 'daarom-antwoord' nimmer bevrediging zal geven, besluit ik een wedervraag te stellen en informeer ik hoe zij het eigenlijk vindt om hier te wonen. 'Armoedig,' antwoordt ze zonder omhaal en vol overtuiging.
'Armoedig klein kamertje. Armoedige porties eten, vaak te lang doorgekookt. En met de mensen die hier wonen, heb ik helemaal geen aansluiting.' De waardering komt duidelijk niet eens in de buurt van de zesmin.

'En het personeel, wat vindt u daarvan?' vraag ik, zoals altijd op zoek naar lichtpuntjes. 'Ik zie heel veel verschillende mensen die het goed bedoelen en die van alles voor me willen regelen,' zegt mevrouw Van Dalen. 'Maar ik kan nog alles zelf.'

Vervolgens ontspint zich een mooi gesprek over hoe zij in vroeger tijden in het leven stond. Altijd gewoond in een groot huis in Amstelveen. Nooit hulp in de huishouding gehad. Drie kinderen alleen opgevoed omdat haar echtgenoot heel vroeg overleed en die opvoeding gecombineerd met een baan als kleuterjuf. Een bijzonder sterke vrouw, kortom, met een dito behoefte aan zelfstandigheid. Ook een vrouw die om begrijpelijke redenen in het verpleeghuis woont gezien het snelle verloop van haar dementie en het daarmee gepaard gaande onvermogen voor zichzelf te zorgen. Maar doordat haar langetermijngeheugen nog goed functioneert, weet ze nog hoe het vroeger was en is het dus net zo begrijpelijk dat acclimatiseren haar zwaar valt.

Het is een goed gesprek, maar dan moet ik weer mijn weg vervolgen omdat zorgverleners dat nu eenmaal altijd moeten doen. Wanneer ik de huiskamer verlaat, stapt zuster Anna net binnen met meneer Dekker. 'Waarom ben ik hier eigenlijk?' hoor ik mevrouw Van Dalen aan haar vragen. Ook vandaag zal niemand haar het juiste antwoord kunnen geven. 